\title{
Pre-Service Teachers`Competencies and Perceptions of Necessity about Practical Tools for Content Development
}

\section{Esra Eren}

Asist. Prof., Eskişehir Osmangazi University, Turkey, eeren@ogu.edu.tr

\section{Zeynep Yurtseven Avci}

Dr., Eskişehir Osmangazi University, Turkey, zavci@ogu.edu.tr

\section{Munise Seckin Kapucu}

Asist. Prof., Eskişehir Osmangazi University, Turkey, muniseseckin@hotmail.com

\begin{abstract}
The purpose of the study is to investigate pre-service teachers competencies and their perceptions of necessity about using practical tools for content development. The study was designed using pre- and post-test experimental design method. The study group consisted of 170 pre-service teachers at a public university in Turkey. The Practical Tools for Content Development (PTCD) scale was used for data collection. Pre-service teachers had been trained about practical tools for 14 weeks during the Computer II course in spring semester. For the data analysis; descriptive statistics, independent t-test, dependent t-test and single factor variance analysis (ANOVA) methods were applied. It was observed that the competency levels of pre-service teachers increased from medium to high. A slight decrease was observed in pre-service teachers perceptions of necessity. No significant differences were observed in competency levels of pre-service teachers depending on gender, department and daily internet use variables. Female participants' level of perceptions of necessity was significantly higher than the the males, whereas there was no other significant differences. It can be concluded that Computer II course might have an important role to improve pre-service teachers' competencies and skills on the use of practical tools for content development.
\end{abstract}

Keywords: Practical content development tools, teacher candidates, Computer II course, competencies, perceptions

\section{INTRODUCTION}

The effects of technology in educational settings have been discussed more and more every day with the rapid changes in information and communication technologies. Technology is an assistive system to support learning of the content and its use will address many aspects of 21 st century learning (Vockley, 2008). Pre-service teachers are expected to have not only content and pedagogical knowledge, but also the 
technological knowledge and skills to address diverse student needs in today's classroom.

Starting with the "Movement of Enhancing Opportunities and Improving Technology" project, abbreviated as FATIH that will be used in rest of this study, which was initiated and carried out by Ministry of National Education (abbreviated as MEB in Turkish); classrooms have been equipped with interactive whiteboards and teachers and students have been distributed tablet computers. This revision in Turkish schools has raised a crucial need for e-content. The studies evaluating FATIH project emphasize the need for high quality e-content that well aligns with the project aims (Banoğlu, Madenoğlu, Uysal \& Dede, 2014; Keleş, Öksüz \& Bahçekapıl1, 2013; Keser \& Çetinkaya, 2013; Yıldız, Sarıtepeci \& Seferoğlu, 2013). To meet the need of e-content, private organizations, teachers, and MEB staff shared e-content that they created via Information Network in Education website, abbreviated as EBA that will be used in rest of the study. Moreover, in-service trainings have been organized to train teachers about designing technology supported courses using e-content (MEB, 2014).

Another prominent issue following the implementation of FATIH project is the technological competencies of teachers, including e-content development skills. According to the required teacher competencies that were prepared by MEB, teachers are expected to use information and communication technologies effectively (MEB, 2008). However, many studies exploring teachers` technological skills report that teachers have low self-efficacy about developing e-content (Hırça \& Genç, 2012; Keleş et al., 2013). Similarly, having unsufficient technology competencies after taking undergraduate courses is also reported for pre-service teachers (Aksüt, Keyvanoğlu \& Balıkçı, 2013; Beşoluk, Kurbanoğlu \& Önder, 2010; Erdemir, Bakırcı \& Eyduran, 2009). Additionally, studies demonstrate the need for teachers to have in-service training about e-content development and usage (Aktaş, Gökoğlu, Turgut \& Karal, 2014; Balc1, Gökkaya \& Kar, 2013; Günbayı \& Yörük, 2014); and the need of preservice training for teachers featuring the knowledge and skill for developing e-content (Akıncı, Kurtoğlu \& Seferoğlu, 2012; Aktaş, Özmen \& Bilgin, 2012; Balcı et al., 2013; Çetin, Çalışkan \& Menzi, 2012; Çuhadar \& Yücel, 2010; Günbayı \& Yörük, 2014).

The exploration of in-service trainings organized by MEB to increase teachers` econtent development skills shows that the trainings are short term (30 hours) and mostly about helping teachers to utilize e-content that already exists in their classes. On the other hand, MEB has been providing face-to-face and online trainings through certain websites (e.g. kursiyer.net, eba.gov.tr) about some content development software (e.g. Flash, Photoshop, and HTML5) (MEB, 2014). However, learning those software products and developing content using those technologies requires spending a lot of time and effort. In this regard, teachers prefer to use the e-content already available; but they have difficulty in finding the e-content appropriate for their instructional goals. In this study, technologies that can be used by teachers to develop e-content in short period of times and aligns well with their instructional goals were investigated and they were named as "practical tools for content development". 
According to the Technology Acceptance Model, which aims to determine the factors influencing a person`s adoption of technology, it is critical that the person believes the technology will be helpful and easy to use (Davis, 1989). If the technology is easy to use, then the person has an intention to use the technology. If the person finds technology hard to use, she/he will not adopt the technology even if she/he believes that it will be helpful (Davis, Bagozzi \& Warshaw 1989; as cited in Aktaş et al., 2014). In this sense, it is foreseen that practical tools for content development will be highly beneficial for teachers and pre-service teachers who wish to develop e-content, but lacking programming skills.

Practical tools for content development are defined as the internet-based technologies that do not require installation and do not require having any computer programming skills (Eren, Yurtseven Avcı \& Seçkin Kapucu, 2014). This term was first used by Çiçek and Yazar (2013) suggesting that preparation of content using internet technologies mostly take long time and effort, but practical content development tools make this process much shorter and easier. Additionally, most of them have free versions. Most of the practical content development technologies emerge as Web 2.0 tools. Web 2.0 tools, are generally inexpensive or free to use, easy to learn, and require few curricular changes for teachers to implement within the classroom (Butler, 2012; Horzum, 2007; McLoughlin \& Lee, 2007). There is currently a large range of Web 2.0 technologies available for educators featuring effective teaching and learning activities (Hew \& Cheung, 2013, Meyer, 2010). The literature review about Web 2.0 technologies showed that most of the studies are about blogs, wikis, podcasts and social networks; and the use of these technologies for communication and collaboration purposes (Ertmer at al., 2011; Meyer, 2010; Usluel \& Mazman, 2009).

Uzunboylu, Bicen and Cavus (2010) conducted a study with pre-service teachers who take Material Development for Educational Technology course. During the course, preservice teachers used Web 2.0 tools (podcasts, vidcasts, slideshare, broadcasts, screencasts, surveys etc.) and Windows Live Spaces for 12 weeks. The authors applied a pre- and post-test. According to the results, teacher candidates provided their opinion as that the web based learning environment should be used in other lessons as well. Another study on pre-service teachers' perceptions of Web 2.0 tools (Eyyam, Meneviş \& Doğruer, 2011) reported that most of the teacher candidates stated positive perceptions about the effectiveness of Web 2.0 technologies for having better atmosphere in the classroom and providing support to the lessons. The results of the study by Baltac1-Göktalay and Özdilek (2010) were similar saying that pre-service teachers' perceptions about Web 2.0 technologies in their learning process were positive and their acceptance and willingness to use Web 2.0 tools were high.

When the results of all reviewed studies were analyzed, it can be concluded that Web 2.0 tools might contribute to the improvement of teaching-learning process. On the other hand, it was observed that most of the studies are about using Web 2.0 tools for communication, interaction, and collaboration purposes. In this study, pre-service teachers used various Web 2.0 technologies for content development purposes related to the topics of their disciplines. Meyer (2010) emphasized the need of additional studies 
enlarging our understanding of individual tools with carefully designed comparisons of different tools using a variety of measures. This study differs from the reviewed studies, since technologies were used for content development by pre-service teachers.

Making use of visual features of emerging tools and conducting research on effective teaching strategies for using these tools is essential in today' classrooms (Arıkan, 2009). It is also highly important to prepare teacher candidates for contemporary teaching and learning environments and equip them with necessary competencies. Use of technology in schools becomes much more widespread in Turkey after the FATIH project, which requires teachers and students to actively use certain technologies in the teachinglearning process. In this sense, training pre-service teachers about using certain technologies, which are easy to use and do not require programming skills, will be promising in terms of increasing their adoption of technology in their future teaching regardless of their department and computer skills (Hırça \& Genç, 2012).

The purpose of this study is to investigate pre-service teachers` competencies and perceptions of necessity about practical tools for content development. In this study, we are addressing the following questions:

- What are the competency and perception of necessity levels of pre-service teachers for using practical tools for content development?

- Is there a significant difference between pre-service teachers' pre-test and post-test scores regarding their competencies and perceptions of necessity about using practical tools for content development?

- Have pre- service teachers' pre-test and post-test scores differed with respect to their gender, department, and daily Internet use for competency and perception of necessity dimensions?

\section{METHOD}

\section{Design of the study}

The single-group pretest-posttest design was applied in the study. Experimental design is reported as the best method to analyze cause-and-effect relationships among variables (Fraenkel \& Wallen, 2006). Therefore, the experimental design was chosen in this study.

\section{Participants}

The study group consisted of 170 pre-service teachers from departments of Science and Technology Education, Mathematics Education, Elementary Education and English Education. Purposive and easily accessible sampling methods were used. In order to determine pre-service teachers from the available sample, criterion sampling has been used. The participation criterion was taking Computer II class for the current semester. To avoid any possible impacts on participants` behaviors, they were not informed about the experimental conditions and tests (Eckhardt ve Ermann, 1977; Karasar, 1995; Spyridakisi; 1992 as cited in Büyüköztürk, 2007). The data of the participants who either did not have pre-test or posttest, and who did not complete the tests carefully were 
not included in the statistical analysis, 33 participants in total. All of the analyses were done with the data from 170 pre-service teachers except the analysis about the gender differences. The analysis about the gender differences were conducted with the data from 169 of the participants, since one participant did not provided her/his gender information. The number of female participant was higher than the males. The number of participants from different departments was ranged from 33 to 57. Pre-service teachers' daily internet use was commonly about 1-2 hours.

\section{Research instrument}

PTCD Scale that was developed by Eren, Yurtseven Avcı and Seçkin Kapucu (2014) was used to collect data of the study. The scale consists of 26 items related to skills required to perform a task using practical tools for content development. The following items, namely "Preparing fliers/ posters", "Concept mapping", "Preparing educational games" and "Creating interactive e-books" that were covered in the original scale were excluded from this study, since students were either not introduced those technologies or spent really short time for using them. Pre-service teachers were asked to express their opinions about their competence and the necessity of those tasks. They reported their opinions on a 5-point Likert-type rating scale for positive and negative perceptions, "1" indicating they strongly disagree and " 5 " indicating they strongly agree. The scale has one dimensional structure and consists of 26 items measuring two characteristics (competency and necessity). The factor weights of the scale items varied between 0.890.48 for competency and between 0.93-0.40 for necessity. Cronbach alpha coefficient was calculated for the reliability of the scale. Cronbach alpha internal consistency coefficients of the scale were $\alpha=0.93$ for the "competency" characteristic and $\alpha=0.95$ for "perception of necessity" characteristic. Cronbach alpha coefficient being higher than 0.80 means that scale is a highly reliable (Özdamar, 1999).

\section{Research procedures}

To investigate pre-service teachers' competencies regarding developing content using practical tools and their perceptions of necessity for having those skills, the Practical Tools for Content Development Scale (PTCD) was applied to all participants as the pretest prior to staring training about those technologies. Before starting the instruction, lesson plans have been prepared by the instructors, who are two of the researchers. Most of the class instructions were done by one of researchers starting from the week after the pre-test was applied. The whole semester was around 14 weeks. During this period preservice teachers were introduced several tools for content development including: presentation tools, video creation tools, digital story-telling tools, e-book preparation tools, communication and collaboration tools such as Google Documents and Blogs.

In-class sessions were based on application by the instructor and students synchronously. The instructor was presenting each single step to use the tools; while students were following the instructor from a big screen that was connected to a projector. Students had individual computers (a small number of students worked together) in the computer laboratory during the class period. They were asked to accomplish a small in-class assignment for the sample application that was demonstrated 
by the instructor. Then students had weekly homeworks; creating learning materials about the topics that they have chosen from their field of study, using the tools that they have learned. Their in-class and outside of class assignments were graded regularly and their grades were declared in the class' Learning Management System (LMS), Moodle site. Students were also uploading their assignments to the related part of the Moodle system. At the end of the semester PTCD Scale was re-applied to all participants as the post-test.

\section{Data analysis}

Responses to the PTCD Scale were analyzed using SPSS software. Frequencies, means, and standard deviations were computed as the descriptive statistics. In addition to the descriptive statistics; independent t-tests, dependent t-tests, and variance analysis for single factor (ANOVA) were conducted. The internal and external factors that might adversely affect the validity of the study were controlled or avoided. Fraenkel and Wallen (2006) suggest some influencing factors for internal and external validity as: characteristics of the subjects, subject loss including location, data collection, pre-test effect, the history of the subject. The participants of this study had similar characteristics. None of them have taken Computer II course before and they did not have experience with practical tools for content development. To diminish the subject loss effect, the study was started with a large group of participants. Data collection instruments were given to the participants by the same person. The data were collected from 203 students. The number of participants was reduced to 170; since some of the participants either did not complete the pre-test or post-test. All four classes had the same instructor to control the instructor effect. All of the sessions were in the same computer laboratories.

To determine pre-service teachers` competencies and perceptions of necessity about using practical tools for content development; the lower and upper bounds were calculated for each interval $(5-1=4)$ according to the interval coefficient $(4 / 5=0,80)$, assuming that each interval was equal in the scale. Then three levels were identified to evaluate pre-service teachers' competency and perception of necessity about using practical tools for content development. Based on these calculations, each statement in the scale was placed in one of the following three categories: low (1.00-2.60; incompetent and not competent); medium (2.61-3.40; moderately competent); and high (3.41-5.00; competent and very competent).

\section{FINDINGS}

In this study, two dependent variables, pre-service teachers` competencies and perceptions of necessity about using practical tools for content development, were analyzed with respect to three independent variables. In this section, means and standard deviations for pre- and post-tests, t-test results comparing the pre- and post-test scores for the whole group; results of the independent t-test according to gender, and the results of the variances analysis in terms of department and daily internet use variables are presented. The results of the descriptive statistics for pre- and post-tests to determine 
pre-service teachers` levels of competencies and perceptions of necessity about using practical tools were provided in Table 1.

Table 1: Descriptive statistics for pre-service teachers' levels of competencies and perceptions of necessity about using practical tools

\begin{tabular}{lccccc}
\hline & $N$ & Minimum & Maximum & $\bar{X}$ & $S s$ \\
\hline Competency & & & & & \\
\hline Pre-test & 170 & 1.09 & 4.82 & 2.74 & .61 \\
Post-test & 167 & 2.41 & 5.00 & 3.76 & .49 \\
\hline Necessity & & & & & \\
\hline Pre-test & 170 & 1.00 & 5.00 & 3.74 & .69 \\
Post-test & 169 & 1.50 & 5.00 & 3.59 & .74 \\
\hline
\end{tabular}

According to Table 1, the competency level of pre-service teachers was medium before taking Computer II course, whereas it became high after taking the course. Even if there was a slight decrease on the perception of necessity of pre-service teachers after taking the course, it was still in the range of high level.

A dependent t-test was conducted to examine whether there was a significant difference between the pre- and post-test scores of the pre-service teachers regarding the scale. Table 2 provides the results of the t-test for the competency and perception of necessity dimensions.

Table2: Comparison of pre-test and post-test scores of pre-service teachers' competency and perception of necessity

\begin{tabular}{|c|c|c|c|c|c|c|}
\hline & $N$ & $\bar{x}$ & $S d$ & $d f$ & $T$ & $P$ \\
\hline \multicolumn{7}{|c|}{ Competency } \\
\hline Pre-test & 170 & 2.74 & 0.61 & 166 & 18.013 & $.000^{*}$ \\
\hline Post-test & 170 & 3.76 & 0.49 & & & \\
\hline \multicolumn{7}{|l|}{ Necessity } \\
\hline Pre-test & 170 & 3.74 & 0.70 & 168 & 2.351 & $.020^{*}$ \\
\hline Post-test & 170 & 3.59 & 0.75 & & & \\
\hline
\end{tabular}

As seen in Table 2, there was a significant difference between the pre- and post-test scores for the scale $\left(\mathrm{t}_{(166)}=18.013, \mathrm{p}<.05\right)$. These results indicates that Computer II course contributed to the development of pre-service teachers' competencies about using practical tools for content development in all aspects of the scale and led to a positive change in their competency scores. When we examine necessity dimension, we see that there was a significant difference between the pre- and post-test scores $\left(t{ }_{(168)}=\right.$ $2,351, \mathrm{p}<.05)$. These results indicates that there was a negative change in pre-service teachers perceptions of necessity about using practical tools for content development for the scale after taking the Computer II course.

Second, we examined whether pre-service teachers` pre- and post-test scores regarding to their competencies and perceptions of necessity about using practical tools for content development differed with respect to their gender. Independent t-test results are displayed in Table 3 for the competency and perception of necessity dimensions. 
Table 3: Comparison of competency and perception of necessity levels of pre-service teachers according to gender variable

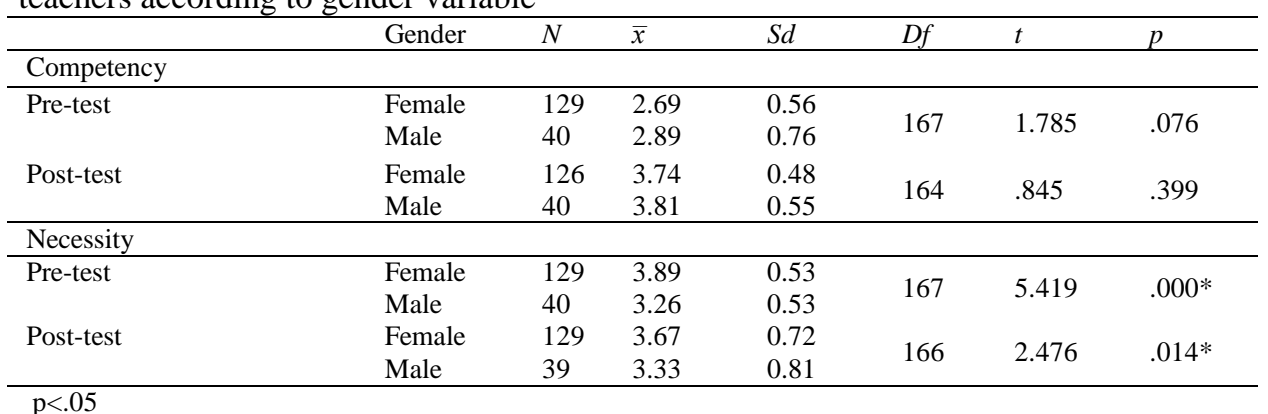

As seen in Table 3, although there was a difference between the female and male preservice teachers' competency levels before and after the training, this difference was not significant (pre-test: $\mathrm{t}_{(167)}=1.785, \mathrm{p}>.05$ and post-test: $\mathrm{t}_{(164)}=.845, \mathrm{p}>.05$ ). When we examine Table 3 , we observe a significant difference between male and female preservice teachers' perception of necessity scores, for both pre- and post-tests (pre-test: $t$ $(167)=5.419, \mathrm{p}<.05$ and post-test: $\left.\mathrm{t}_{(164)}=2.476, \mathrm{p}<.05\right)$.

Then, pre-service teachers' pre- and post-test scores for their competencies and perceptions of necessity were analyzed according to their departments; and no significant differences were observed (pre-test: $\mathrm{F}_{(3-169)}=1.297, \mathrm{p}=.299>.05$ and posttest: $F_{(3-166)}=1,420, p=.239>.05$ for the competency; (pre-test: $F_{(3-169)}=1.738$, $\mathrm{p}=.161>.05$ and post-test: $\mathrm{F}_{(3-168)}=1.030, \mathrm{p}=.381>.05$ for the necessity) according to their departments.

Lastly, pre-service teachers' pre- and post-test scores for their competencies and perceptions of necessity was examined according to their daily internet usage; and no significant differences were observed (pre-test: $\mathrm{F}_{(3-168)}=1.236, \mathrm{p}=.299>.05$ and posttest: $\mathrm{F}_{(3-165)}=.207, \mathrm{p}=.892>.05$ for the competency; (pre-test: $\mathrm{F}_{(3-168)}=1.68, \mathrm{p}=.174>.05$ and post-test: $\mathrm{F}_{(3-167)}=.636, \mathrm{p}=.593>.05$ for the necessity) according to their daily internet usage time.

\section{DISCUSSIONS and SUGGESTIONS}

In this study, pre-service teachers` competencies and perceptions of necessity about practical tools for content development were examined applying single-group pre- and post-test experimental design. According to the pre-test results, the competency level of pre-service teachers was medium before taking Computer II course. This finding is parallel with the results of the studies conducted by Çetin et al. (2012) and Şendağ (2014) where the authors reported that pre-service teachers have medium technology skills. Similarly, Çuhadar and Yücel (2010), and Kabakçı Yurdakul (2011) reports that most of the pre-service teachers reported that they are confident about using information and communication technologies. On the other hand, studies report that even if preservice teachers report high levels of confidence to use technology for instructional 
purposes, they report the need for further training in this regard (e.g. Beşoluk et al., 2010; Aksüt et al., 2013).

A recent study on pre-service teachers' access and use of internet Technologies (Çukurbaşı \& İşman, 2014) suggest that pre-service teachers widely use Web 2.0 technologies. Although today's pre-service teachers are proficient in using social and communications technologies, they are not well prepared to use Web 2.0 technologies for teaching and learning (Lei, 2009). In this study, pre-service teachers had high level of competency for using practical tools for content development after taking Computer II course. In this regard, it can be interpreted that the training that pre-service teachers received during the course were effective to help them improving their skills using these technologies.

According to the pre-test results, pre-service teachers' perceptions of necessity levels were high implying that pre-service teachers believe that these technologies are necessary in education. This finding is parallel with the results of the studies by Ertmer et al. (2011), Lei (2009), Sadaf (2012), and Uzunboylu et al. (2011). Similarly, Baltac1Göktalay and Özdilek (2010) reported positive perceptions and high levels of acceptance and willingness to use about web 2.0 technologies. Today, it is suggested that pre-service teachers` daily technology use positively affect their perceptions of use of those technologies for educational purposes. As a matter of fact, the results of this study and reviewed studies indicates that pre-service teachers beliefs about effectiveness of technology use in education and they need further training about using technology for educational purposes.

On the other hand, there was a slight decrease on the perceptions of necessity of preservice teachers after completing the course, even if it was still in the range of high level. This fact may be due to many different factors. It can be said that some preservice teachers had really high expectations for the course that were not fully met. Another reason could be that: since a high number of new technologies were introduced to the pre-service teachers, they could not spend adequate time to learn about various uses of certain Technologies and/or they were bored of the high number of assignments. When the results were analyzed by items, it was seen that there was an increase of the level of perceptions of necessity for the "preparing presentation" and "preparing interactive presentations" items; and the "preparing tests" item had the highest mean implying that pre-service teachers believe that presentation tools and assessment tools would be most necessary/useful tools for their future instruction.

Finally, the differentiation of pre- service teachers' competency and perception of necessity according to their gender, department, and daily internet use has been addressed. According to the results of the statistical analysis, even if male participants had higher competency scores than the females, this difference was not statistically significant. This finding is parallel with the results of related studies (e.g. Çetin et al., 2012; Meriç, 2014). Additionally, it was observed that female students' level of perceptions of necessity was significantly higher than males for both pre- and post-test. This result can be interpreted as: female pre-service teacher believe the effectiveness of practical tools more than males, so they are expected to be more willing to learn about 
these technologies. There were not any significant difference among pre-service teachers according to their departments and daily internet use for both competency and perception of necessity characteristics. The finding about the departments differs from the results of Çetin et al. (2012). One reason for that there was no significant difference between pre-service teachers' competencies and perceptions of necessity with respect to their departments can be that the study group had a homogeneous structure, since it contains freshmans and sophomores. Another reason can be that the needs of all four departments were considered while choosing the technologies that will be introduced to pre-service teachers during the course.

As mentioned earlier, the development of e-content is one of the five major components of FATIH Project. In this regard, it is believed that teaching pre-service teachers the technologies to help them to create e-content might contribute to the success of the project. At the same time, these technologies could be a part of in-service teacher training programs. On the other hand, Aksüt at al. (2013) recognize the deficiency of undergraduate level Computer II courses. It was claimed that the current scope of computer courses (computer supported education, evaluation and selection of course software, etc.) are inadequate to meet the needs of pre-service teachers. In this study, it was observed that pre-service teachers had higher competency about using practical tools after taking Computer II class. The scope of Computer II courses could be updated to include practical tools for content development. Additionally one semester was really short for pre-service teachers to learn about practical tools. Elective courses that preservice teachers could get more comprehensive training about different practical tools could be offered. Pre-service teachers could also apply their knowledge from Computer II course to their courses in future semesters, such as Instructional Technology and Material Design and Special Instructional Methods I- II. In this study, the same tools were used by pre-service teachers from Science and Technology Education, Mathematics Education, Elementary Education, and English Education. However, since different departments might have different needs, the practical tools and applications could be selected specific to the program. This study was conducted with students who took Computer II class to have similarity in terms of participants' characteristics, but this fact limited the variety. These technologies could be introduced to the students from other departments and additional studies can be conducted to increase the validity and reliability of this study.

\section{REFERENCES}

Akıncı, A., Kurtoğlu, M. \& Seferoğlu, S. S. (2012). Bir teknoloji politikası olarak FATïH projesinin başarılı olması için yapılması gerekenler: Bir durum analizi çalışması. Akademik Bilişim Konferansl, Akdeniz Üniversitesi, Antalya.

Aksüt, M., Keyvanoğlu, A. A. \& Balıkçı, Ç. (2013). Sınıf öğretmeni adaylarının bilişim teknolojilerine ilişkin görüşleri. Akademik Bilişim Konferansı, Akdeniz Üniversitesi, Antalya.

Aktaş, İ., Gökoğlu, S., Turgut, Y. E. \& Karal, H. (2014). Teachers' opinions about FATIH project: Awareness, foresight and expectations. Necatibey Eğitim Fakültesi Elektronik Fen ve Matematik Eğitimi Dergisi (EFMED), 8 (1), 257-286. 


\begin{abstract}
Aktaş, İ., Özmen, H., \& Bilgin, İ. (2012). Examination of the science student teachers' views about the FATIH project. 6th International Computer and Instructional Technologies Symposium, Gaziantep, Turkey.
\end{abstract}

Arıkan, Y. D. (2009). Bilişim teknolojileri öğretmen adayları ve öğretmenlik uygulaması dersi. Ege Eğitim Dergisi, 10(1), 1-23.

Balcı, E. Ö., Gökkaya, Z. \& Kar, A. (2013). FATïH Projesinin üniversiteler yüzü. İstanbul Sosyal Bilimler Dergisi, 5, 13-30.

Baltacı-Göktalay, S., \& Özdilek, Z. (2010). Pre-service teachers' perceptions about web 2.0 technologies. Procedia-Social and Behavioral Sciences, 2(2), 4737-4741.

Banoğlu, K., Madenoğlu, C., Uysal, Ş. \& Dede, A. (2014). FATİH projesine yönelik öğretmen görüşlerinin incelenmesi (Eskişehir ili örneği). Eğitim Bilimleri Araştırmaları Dergisi, 4 (Özel Sayı 1), 39-58.

Beşoluk, Ş., Kurbanoğlu, N. İ. \& Önder, İ. (2010). Educational technology usage of preservice and in-service science and technology teachers. Elementary Education Online, 9(1), 389-395, 2010.

Butler, J. (2012). Grappling with change: Web 2.0 and teacher education. In D. Polly, C. Mims, \& K. A. Persichitte (Eds.), Developing Technology-Rich Teacher Education Programs: Key Issues. IGI Global: Hershey, PA.

Büyüköztürk, Ş. (2007). Deneysel desenler: Ön test son test kontrol gruplu desen. Ankara: Pegem Yayınları.

Connolly, T. M., Hainey, T., Baxter, G. J., Stansfield, M. H., Gould, C., Can, C., \& Dimitrova, N. (2011). Teachers' views on Web 2.0 in education: An evaluation of a largescale European pilot. In Next Generation Web Services Practices (NWeSP), 7th International Conference on (pp. 517-522).IEEE.

Çetin, O., Çalışkan, E. \& Menzi, N. (2012).Öğretmen adaylarının teknoloji yeterlilikleri ile teknolojiye yönelik tutumları arasındaki ilişki. İlköğretim Online, 11(2), 273-291.

Çiçek, M., \& Yazar, B. (2013). Pratik içerik geliştirme teknolojilerinin uzaktan eğitimdeki önemi. Retrieved from http://www.tutev.org.tr/includes/fckeditor/dosyalar/files/ic erik_gelistirme_ab_2013.pdf on 18.11.2014.

Çuhadar, C. \& Yücel, M. (2010). Yabancı dil öğretmeni adaylarının bilgi ve iletișim teknolojilerinin öğretim amaçlı kullanımına yönelik özyeterlik algıları. Pamukkale Üniversitesi Eğitim Fakültesi Dergisi, 27, 199-210.

Çukurbaşı, B. \& İşman, A. (2014). Öğretmen adaylarının dijital yerli özelliklerinin incelenmesi (Bartın Üniversitesi Örneği). Bartın Üniversitesi Eğitim Fakültesi Dergisi, 3(1), 28-54.

Davis, F. D. (1989). Perceived usefulness, perceived ease of use, and user acceptance of information technology. MIS Quarterly, 13(3), 319-340.

Erdemir, N., Bakırcı, H. \& Eyduran, E. (2009). Öğretmen adaylarının eğitimde teknoloji kullanabilme özgüvenlerinin tespiti. Türk Fen Eğitimi Dergisi, 6(3), s.99-108.

Eren, E., Yurtseven Avc1, Z. \& Seçkin Kapucu, M. (2014). Developing a scale for competencies and perceptions of necessity about using practical tools for content 
development.

Eğitimde Kuram ve Uygulama/Journal of Theory and Practice in Education, 10 (5), 1177-1189.

Ertmer, P. A. Newby, T. J., Yu, J. H., Liu, W., Tomory, A., Lee, Y. M., Sendurur, E. \& Sendurur, P. (2011). Facilitating students' global perspectives: Collaborating with international partners using Web 2.0 technologies. Internet and Higher Education, 14, 251261.

Eyyam, R., Meneviş, İ. \& Doğruer, N. (2011). Perceptions of teacher candidates towards Web 2.0 technologies, Procedia Social and Behavioral Sciences, 15, 2663-2666.

Fraenkel J. R. \& Wallen N. E. 2006. How to design and evaluate research in education. New York: McGraw-Hill.

Günbayı, İ. \& Yörük, T. (2014). Yönetici ve öğretmenlerin eğitimde FATİH projesinin uygulanma düzeyine ilişkin görüşleri (Antalya ili Muratpaşa ilçesi örneği). Eğitim Bilimleri Araştırmaları Dergisi, 4 (1), 189-211.

Hew, K. F. \& Cheung, W. S. (2013). Use of Web 2.0 technologies in K-12 and higher education: The search for evidence-based practice. Educational Research Review, 9, 47-64.

Hırça, N. \& Genç, M. (2012). Fen eğitiminde materyal tasarımı için medya ve teknoloji. Bartın Üniversitesi Eğitim Fakültesi Dergisi, 1(1) 252-260.

Horzum, M. B. (2007). Web tabanlı yeni öğretim teknolojileri: Web 2.0 araçları. Eğitim Bilimleri ve Uygulama, 6 (12), 99-121.

Kabakçı Yurdakul, I. (2011). Öğretmen adaylarının teknopedagojik eğitim yeterliklerinin bilgi ve iletişim teknolojilerini kullanımları açısından incelenmesi. Hacettepe Üniversitesi Eğitim Fakültesi Dergisi/H. U. Journal of Education, 40, 397-408.

Keleş, E., Öksüz, B. D. \& Bahçekapılı, T. (2013). Teknolojinin eğitimde kullanılmasına ilişkin öğretmen görüşleri: FATİH projesi örneği. Gaziantep University Journal of Sciences, 12 (2), 353-366.

Keser, H. \& Çetinkaya, L. (2013). Öğretmen ve öğrencilerin etkileşimli tahta kullanımına yönelik yaşamış oldukları sorunlar ve çözüm önerileri. Turkish Studies - International Periodical for the Languages, Literature and History of Turkish or Turkic, 8 (6), 377-403.

Lei, J. (2009). Digital natives as preservice teachers: What technology preparation is needed? Journal of Computing in Teacher Education, 25(3), 87-97.

McLoughlin, C., \& Lee, M. W. (2007). Social software and participatory learning: Pedagogical choices with technology affordances in the Web 2.0 era. In ICT: Providing choices for learners and learning. Proceedings ascilite Singapore (pp.664-675). Retrieved from http://www.ascilite.org.au/conferences/singapore07/procs/mcloughlin.pdf on 19.11.2014.

MEB, (2008). Öğretmenlik mesleği genel yeterlikleri. Retrieved from http://otmg.meb.gov.tr /YetGenel.html on 24.07.2014.

MEB, (2014). Hizmetiçi Eğitim Dairesi Başkanlığı. Retrieved from http://hedb.meb.gov.tr/n et/ on 02.111.2014. 
Meriç, G. (2014). Fen ve teknoloji öğretmen adaylarının Teknolojik Pedagojik Alan Bilgisi (TPABGÖ) konusunda özgüven seviyelerinin belirlenmesi. Eğitimde Kuram ve Uygulama/Journal of Theory and Practice in Education, 10(2), 352-367.

Meyer, K. A. (2010). A comparison of Web 2.0 tools in a doctoral course. Internet and Higher Education, 13, 226-232.

Özdamar, K. (1999). Paket programlar ile istatistiksel veri analizi. Eskişehir: Kaan Kitabevi.

Sadaf, A. Newby, T. J. \& Ertmer, P. A. (2012). Exploring pre-service teachers' beliefs about using Web 2.0 technologies in K-12 classroom. Computers \& Education, 59, 937-945.

Şendağ, S. (2014). Fen bilgisi öğretmen adaylarının derslerinde bit kullanmaya hazırbulunma durumları: Akdeniz bölgesi örneği. Eğitimde Kuram ve Uygulama Articles Journal of Theory and Practice in Education, 10(5), 1156-1176.

Usluel, Y. K. \& Mazman, S. G. (2009). Adoption process of web 2.0 tools in distance education. Procedia-Social and Behavioral Sciences, 1(1), 818-823.

Uzunboylu, H., Bicen, H. \& Cavus, N. (2011). The efficient virtual learning environment: A case study of web 2.0 tools and Windows live spaces. Computers \& Education, 56, 720-726.

Vockley, (2008). Maximizing the impact: The pivotal role of technology in a 21st century education system. Retrieved from http://www.p21.org/storage/documents/p21setdais tepaper.pdf on 19.11.2014.

Yıldız, H., Sarıtepeci, M. \& Seferoğlu, S. S. (2013). FATİH projesi kapsamında düzenlenen hizmet-içi eğitim etkinliklerinin öğretmenlerin mesleki gelişimine katkılarının ISTE öğretmen standartları açısından incelenmesi. Hacettepe Üniversitesi Ĕ̈itim Fakültesi Dergisi/Hacettepe University Journal of Education, Özel Sayl(1), 375-392.

\section{Turkish Abstract}

Öğretmen Adaylarının Eğitimde Pratik İçerik Geliştirme Araçlarını Kullanma Yeterlilikleri ve Bu Araçların Gerekliliğine İlişkin Algıları

Bu çalışmada, öğretmen adaylarının pratik içerik geliștirme araçlarını kullanma yeterlilikleri ve bunların gerekliliğine ilişkin algılarının incelenmesi amaçlanmıştır. Araştırma, öntest-sontest deneysel yöntemi ile desenlenmiştir. Çalışmaya Türkiye'de bir devlet üniversitesinde öğrenim gören 170 öğretmen adayı katılmıştır. Veri toplama aracı olarak Pratik İçerik Geliştirme Ölçeği (PİGT) kullanılmıştır. Öğretmen adaylarına, Bilgisayar II dersi kapsamında, pratik içerik geliştirme araçlarıyla ilgili bir dönem (14 hafta) boyunca eğitim verilmiştir. Verilerin analizinde, betimleyici istatistikler, bağımsız örneklemeler t-testi, bağımlı örneklemeler t-testi ve tek faktörlü varyans analizinden yararlanılmıştır. Ön-son test sonuçlarına göre, öğretmen adaylarının pratik içerik geliştirme araçlarını kullanım yeterliliklerinin orta düzeyden yüksek düzeye çıktığı görülmüştür. Bununla birlikte söz konusu araçların eğitimde kullanımına yönelik yüksek olan gereklilik algılarının az da olsa düştüğü belirlenmiştir. Öğretmen adaylarının içerik geliştirme teknolojilerine ilișkin yeterliliklerinin cinsiyet, öğrenim görülen program ve günlük internet kullanım süresi değişkenlerine göre anlamlı bir farklılık göstermediği ortaya konmuştur. Öğretmen adaylarının içerik geliştirme teknolojilerinin gerekliliğine ilişkin olarak kadın öğretmen adaylarının algılarının erkeklere göre anlamlı düzeyde yüksek olduğu, diğer değişkenlere göre farklılık olmadığı belirlenmiştir. Araştırmadan elde edilen sonuçlar çerçevesinde Bilgisayar II 
dersinin, öğretmen adaylarının pratik içerik geliştirme teknolojilerini kullanma yeterliliklerini ve becerilerini geliştirmede önemli bir rol üstlenebileceği söylenebilir.

Anahtar Kelimeler: Pratik içerik geliştirme araçları, öğretmen adayları, Bilgisayar II dersi.

\section{French Abstract}

Pré-entretenez Professeurs `Compétences et les Perceptions de Nécessité d'Outils Pratiques pour Développement de Contenu

Le but de l'étude est d'examiner des professeurs de pré service ' des compétences et leurs perceptions de nécessité de l'utilisation d'outils pratiques pour le développement de contenu. L'étude a été conçue utilisant pré et post-tester la méthode de design expérimentale. Le groupe d'étude a consisté en 170 professeurs de pré-service à une université publique en Turquie. Les Outils Pratiques pour le Développement de contenu (PTCD) l'échelle ont été utilisés pour la collecte de données. Pré entretenez des professeurs avait été formé d'outils pratiques pendant 14 semaines pendant l'Ordinateur II cours en semestre à de printemps. Pour l'analyse de données; la statistique descriptive, le t-test indépendant, le t-test dépendant et l'analyse de désaccord de facteur simple (ANOVA) des méthodes ont été appliqués. Il a été observé que les niveaux de compétence de professeurs de pré service ont augmenté du moyen à haut. Une diminution légère a été observée dans des professeurs de pré service `les perceptions de nécessité. Aucune différence significative n'a été observée dans les niveaux de compétence de professeurs de pré service selon le genre, le département et des variables d'utilisation Internet quotidiennes. Le niveau des participants féminins des perceptions de nécessité était significativement plus haut que les mâles, tandis qu'il n'y avait aucune autre différence significative. On peut conclure que l'Ordinateur II cours pourrait avoir un rôle important pour améliorer les compétences des professeurs de pré service et des compétences sur l'utilisation d'outils pratiques pour le développement de contenu.

Mots-clés: Outils de Développement de Contenu Pratiques, Candidats de Professeur, Ordinateur II Cours, Competencie, Perceptions

\section{Arabic Abstract}

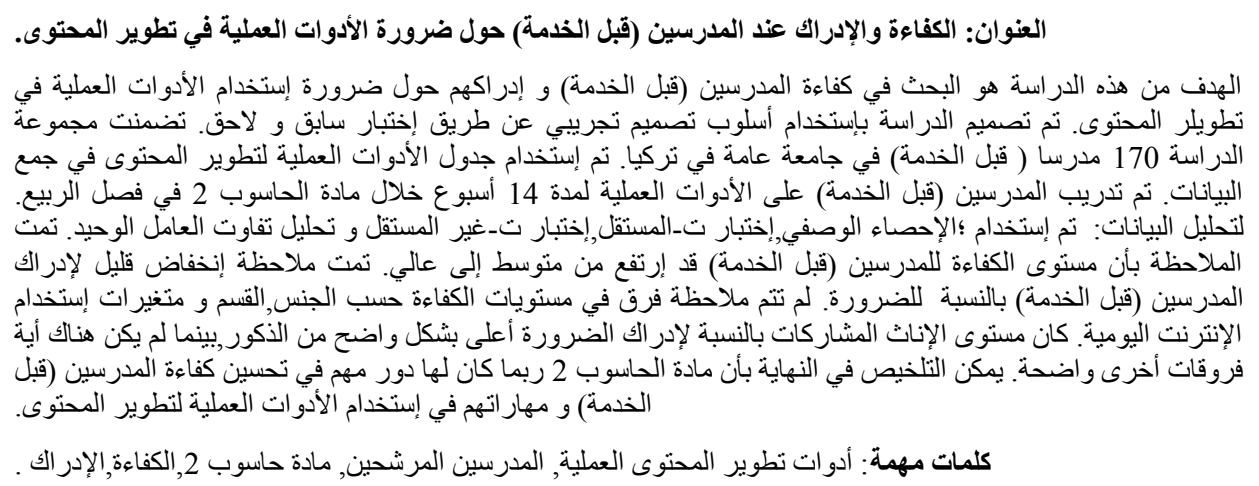

